\title{
Igor Čulig
}

Gradski muzej Karlovac

\section{Zlatko Uzelac}

Institut za povijest umjetnosti, Zagreb, vanjski suradnik

Andrej Žmegač

Institut za povijest umjetnosti, Zagreb

\section{Nedovršeni barokni grad-tvrđava Novi Karlovac}

\author{
Izvorni znanstveni rad - Original scientific paper \\ Primljen - Received 26. 6. 2021. \\ UDK 728.81:[7.034.7+711"17" \\ DOI https://doi.org/10.31664/ripu.2021.45.12
}

\begin{abstract}
Sažetak
U radu se objavljuju dosad nepoznati nacrti planiranoga baroknog grada-tvrdave Novi Karlovac, čija je gradnja započela 1733. nedaleko od Karlovca, kao dio velike strateške cjeline novih gradova-tvrđava na jugoistočnoj granici Habsburške Monarhije. Grad je trebao površinom biti najveći grad-tvrđava u Hrvatskoj, no početkom Rata $z a$ nasljede poljske krune, a potom i smrću princa Eugena Savojskog 1736. gradnja je zaustavljena, a u posve novim okolnostima nakon
\end{abstract}

smrti cara Karla VI. više nije nastavljena. Dotad izgrađeni zemljani nasipi pojedinih fortifikacijskih dijelova i opkopi uz njih ostali su očuvani do danas. Projekti utvrdenoga grada dio su opusa Nicolasa Doxata de Démoreta, glavnog projektanta gradova-tvrđava princa Eugena Savojskog, a pažnju posebno privlači i glavna gradska crkva koja je projektirana kao tlocrtna varijacija bečke Peterskirche.*

Ključne riječi: barokni urbanizam, fortifikacijska arhitektura, novoplanirani gradovi, Karlovac, princ Eugen Savojski, Nicolas Doxat de Démoret, Johann Lucas von Hildebrandt

Ostatci zemljanih nasipa i opkopa započetih bedema velike tvrđave, koja se prema projektu usvojenom 1730. počela intenzivno graditi 1733. godine nasuprot ušću rijeke Korane u Kupu, kilometar udaljenosti zračnom linijom od povijesne jezgre Karlovca, grada-tvrđave 16. stoljeća, očuvani su do danas u znatnoj mjeri onako kako su zabilježeni na nekoliko kartografskih prikaza iz druge polovine 18. stoljeća (sl. 1). ${ }^{1} \mathrm{U}$ međuvremenu je dijelom reguliran potok Orlica, koji teče središtem tvrđave, pa je nekoć močvarno-ujezereni dio potoka u depresiji u središtu prostora okruženog započetim bedemima nešto smanjen, što je omogućilo cjelovitiju parcelaciju zemljišta za privođenje zemljoradnji. Zemljišna parcelacija pri tome danas odaje neke elemente tragova geometrizacije koja potječe od tvrđavske regulacije. Na podignutome zemljanom nasipu jedne gotovo dovršene tvrđavske kontragarde razvilo se groblje sela Donje Mekušje s grobljanskom kapelom (sl. 2), dok je veća kompaktnija cjelina znatnije formiranih bedema i opkopa na sjeveroistočnoj strani danas dijelom prekrivena šumom.

$\mathrm{Na}$ tim se kartografskim prikazima, koji bilježe stanje u drugoj polovini 18. stoljeća, osobito u usporedbi s obližnjim Karlovcem ističe veličina nove tvrđave. $U$ iskazanom opsegu započetih bedema moglo bi se smjestiti i gotovo četiri puta veće gradsko tkivo od onoga postojeće tvrđave Karlovac. Uz to se ističe i bitna oblikovna razlika heksagonalnoga, centralno organiziranog renesansno-manirističkoga grada 


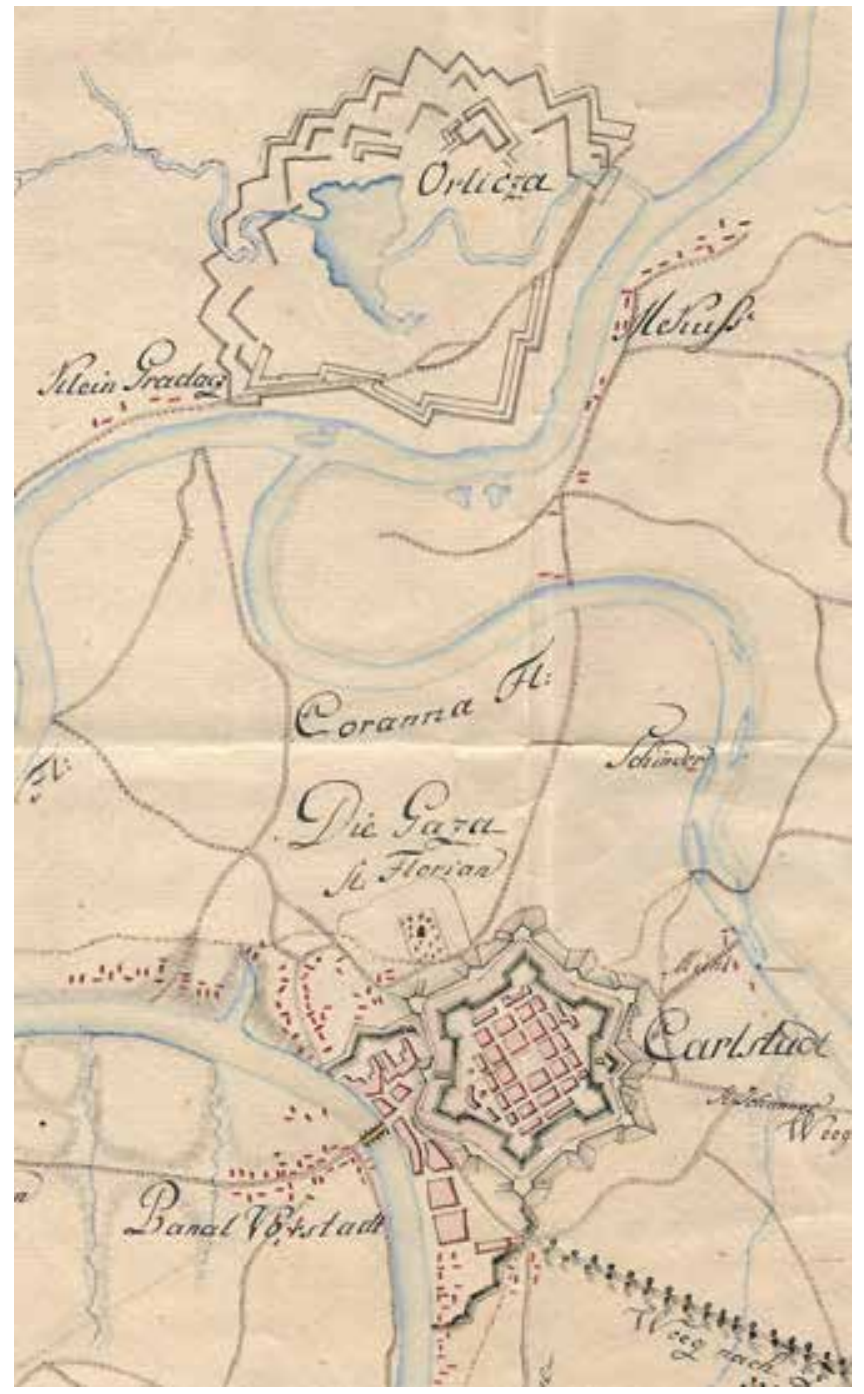

1. Karlovac i Novi Karlovac (Orlica), 1783. (Österreichisches Staatsarchiv, Kriegsarchiv, Beč, G I h 283)

Karlovac and Novi Karlovac (Orlica), 1783 (Österreichisches Staatsarchiv, Kriegsarchiv, Vienna, G I h 283)

i, nasuprot tome, nove tvrđave koja se lepezasto rasprostire u krajoliku na lijevoj obali Kupe. Izrazito joj je naglašena središnja os, oslonjena u vrhu zaokreta rijeke nešto nizvodno od ušća Korane. Pri tome je, slučajno ili ne, os nove tvrđave, koja stoji u otklonu prema sjeverozapadu, praktički paralelna s onom osi simetrije karlovačke šesterokutne zvijezde i tamošnje ulične mreže koju određuje isti stupanj otklona prema sjeverozapadu (sl. 1). Međutim karakteristično je da već na kartografskom prikazu u Prvom vojnom premjeru iz istog vremena, nastalom 1783. godine, upravo dio bedema uz rijeku uopće nije prikazan, nego su fortifikacije predočene shematski i udaljene od zavoja Kupe (sl. 3).

Veličina nove tvrđave, ne samo prema veličini Karlovca, nego i u usporedbi s ostalim gradovima-tvrđavama u Hrvatskoj iz istog vremena - a nova tvrđava površinom je planirana gotovo tri puta većom od najvećega grada-tvrđave Osijeka ${ }^{2}$ - ukazivala je posredno da unutar započetih bedema nije mogla biti zamišljena samo tvrđava, nego da je bio planiran i grad, no izvorni nacrti nisu bili poznati. Jedan dio nacrta iz vremena gradnje, ukupno četiri izvedbena odnosno izvještajna nacrta iz 1734. godine, čuvaju se u Nacionalnoj knjižnici u Budimpešti (Országos Széchényi Könyvtár). ${ }^{3}$ Nisu dosad objavljivani ni analizirani. U Württemberškoj zemaljskoj knjižnici (Württembergische Landesbibliothek) u Stuttgartu

2. Orlica, pogled na ostatke započete tvrđave na lijevoj obali Kupe s ušćem Korane i Karlovcem u pozadini (foto: Paolo Mofardin)

Orlica, view of the remains of the unfinished fortress on the left bank of the Kupa, with the mouth of the Korana and Karlovac in the background

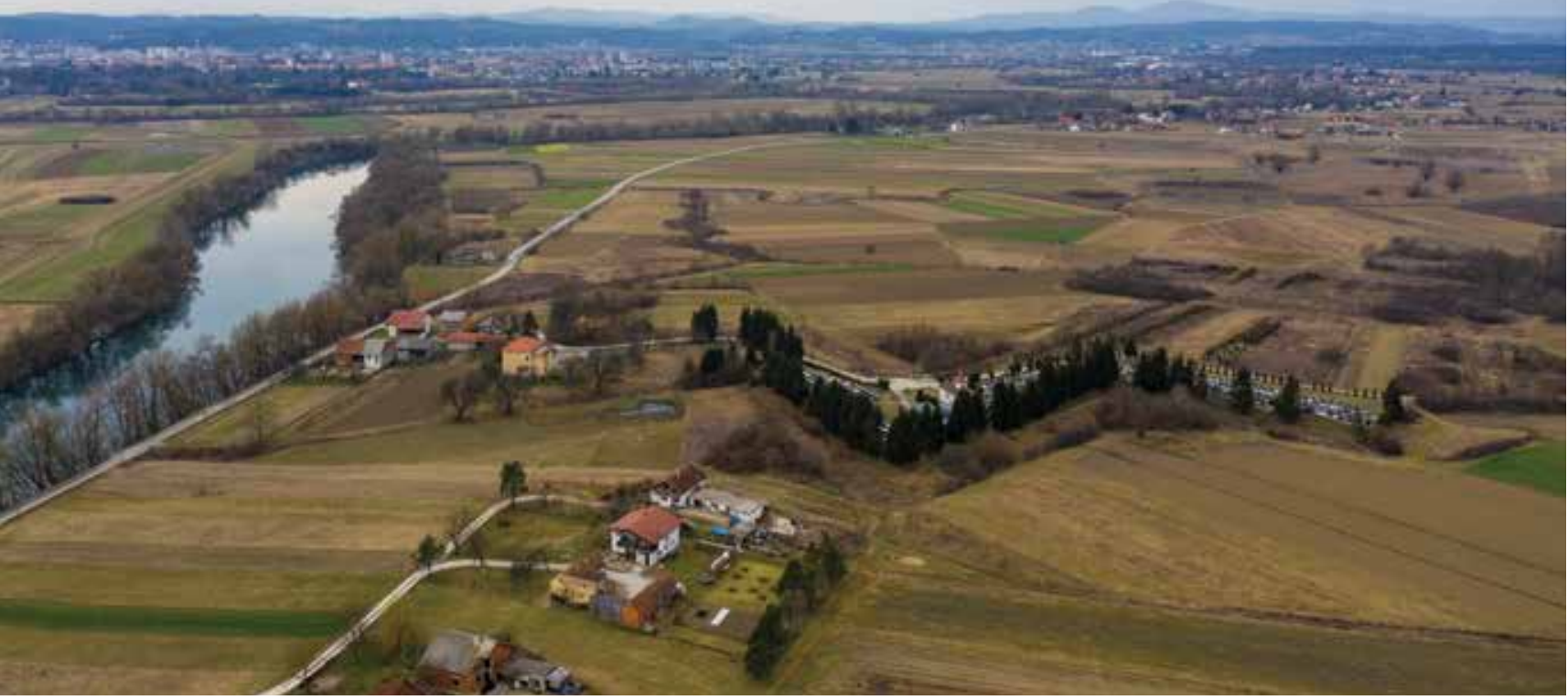




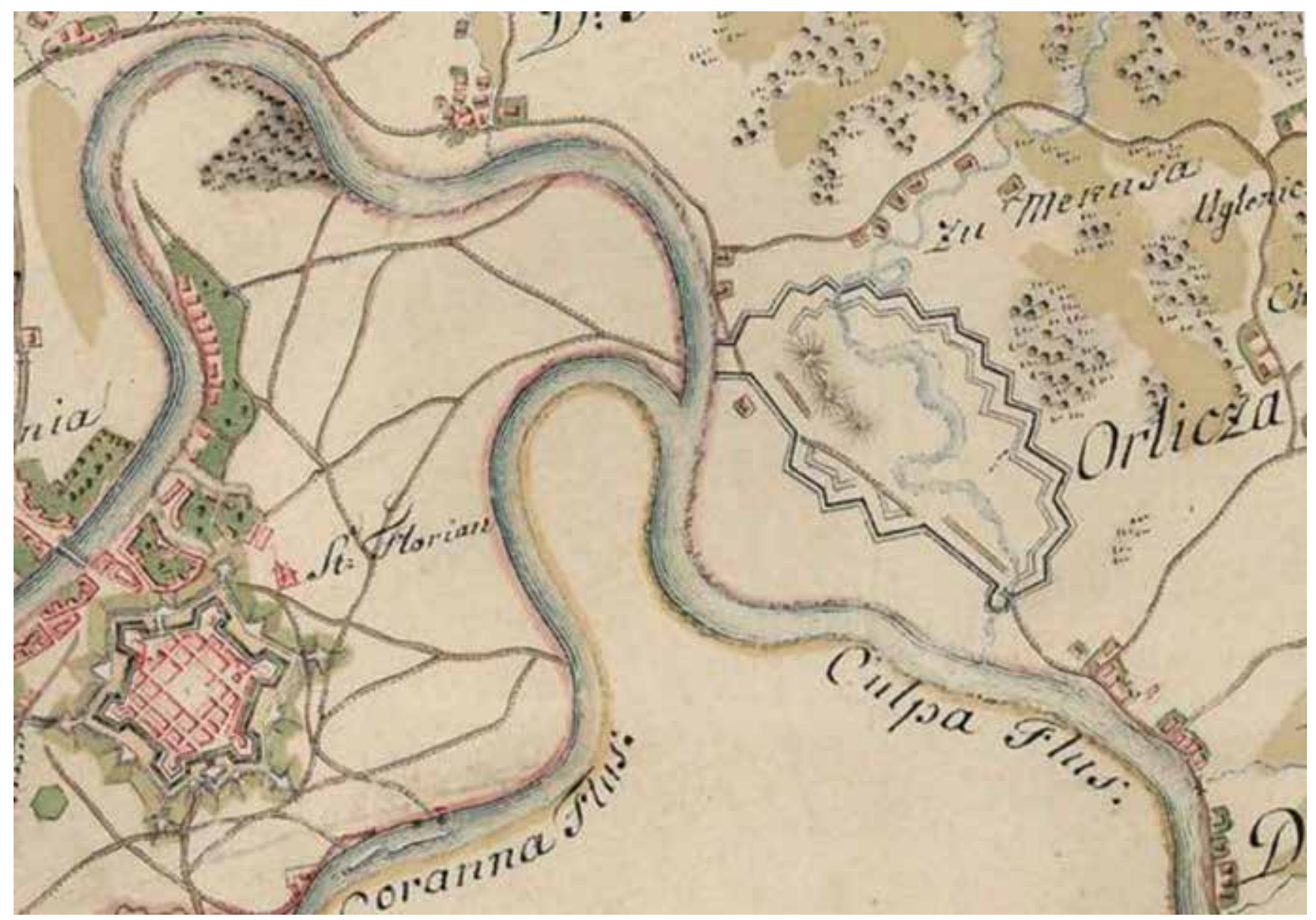

3. Karlovac i Novi Karlovac (Orlica), prikaz na Prvom vojnom premjeru, 1783.

Karlovac and Novi Karlovac (Orlica) as shown in the First Military Survey, 1783

očuvan je pak jedan nacrt s natpisom na francuskom - Nouveau Carlstadt par Doxat, koji vjerojatno predstavlja kopiju prve varijante projekta novoplaniranoga grada. ${ }^{4}$

Na prikazu iz Stuttgarta (sl. 4) vidimo projektiranu tvrđavu lociranu uza zavoj rijeke Kupe, tako da rijeku koristi za svoju zaštitu, pa na toj strani ima jednostavniji sastav bedema, $s$ dvije platforme, a na drugoj, "kopnenoj" strani standardno složen sastav elemenata. Prema kopnu je pet bastiona. Tri srednja su prostranija i u njima su smještene barutane, a dva bočna u blizini rijeke nešto su manja i jednostavnija. Bastioni su koncipirani s uvučenim flankama u gornjem dijelu, a s dodatnim položajem, tzv. niskom flankom u donjem dijelu. Između bastiona, a odvojeni od osnovnog tvrđavnog tijela, stoje ravelini, kojih ima četiri. Oblikovani su originalno jer nemaju šiljat vrh, nego konkavnu frontu; no kao svoju jezgru sadržavaju i zasebnu manju građevinu - redvi (franc. reduit). Možda bi zbog toga moglo biti govora i o dvije zasebne građevine: malenom ravelinu i njegovoj zaštiti, no svakako je riječ o nekonvencionalno zamišljenom sklopu na standardnom mjestu predviđenom za ravelin. Takvi ravelini, kao i bastioni, pred sobom imaju i zaštitu u obliku kontragardi. Te izduljene, uske građevine tvorile su još jedan pojas vanjskih elemenata, produbljujući tako zonu obrane. Sve je, dakako, bilo okruženo uobičajenom glasijom (u tlocrtu "zupčastog" izgleda), slobodnom površinom za što bolji nadzor neprijateljskog približavanja.

Sastav bedema uz rijeku mnogo je jednostavniji, no i ovdje je bila predviđena vrlo ozbiljna zaštita: uočava se izvedba određenih platformi koje bi služile adekvatnom "pokrivanju" tih poteza tvrđave. Platforme su izvedene kako na osnovnom tvrđavnom tijelu, tako i na drugoj strani opkopa, dakle na uskom pojasu uza samu rijeku. Sav prostor oko osnovnog tijela, koji je svakako trebao biti opkop ili šanac, označen je žućkastom bojom. Uobičajeno je u nizinskim utvrdama ta graba bila punjena vodom kako bi stvorila potrebnu zaštitu, pa je nesumnjivo tako trebalo biti i ovdje. Neobično je što ova boja ne sugerira vodu, no nesumnjivo je taj prostor trebao biti plavljen i standardno bi bio označavan plavozeleno, nalik susjednoj rijeci. Znamo da prostorom tvrđave protječe - ovdje neprikazani - potok Orlica, pa bi šančevi tvrđave svakako bili punjeni iz njegovog toka, prije no što se taj potok ulije u Kupu.

Urbano tkivo novoplaniranoga grada-tvrđave projektirano je u potpunom suglasju s fortifikacijama. Organizirano je u cjelini s obzirom na središnju os, koja se proteže od središ- 


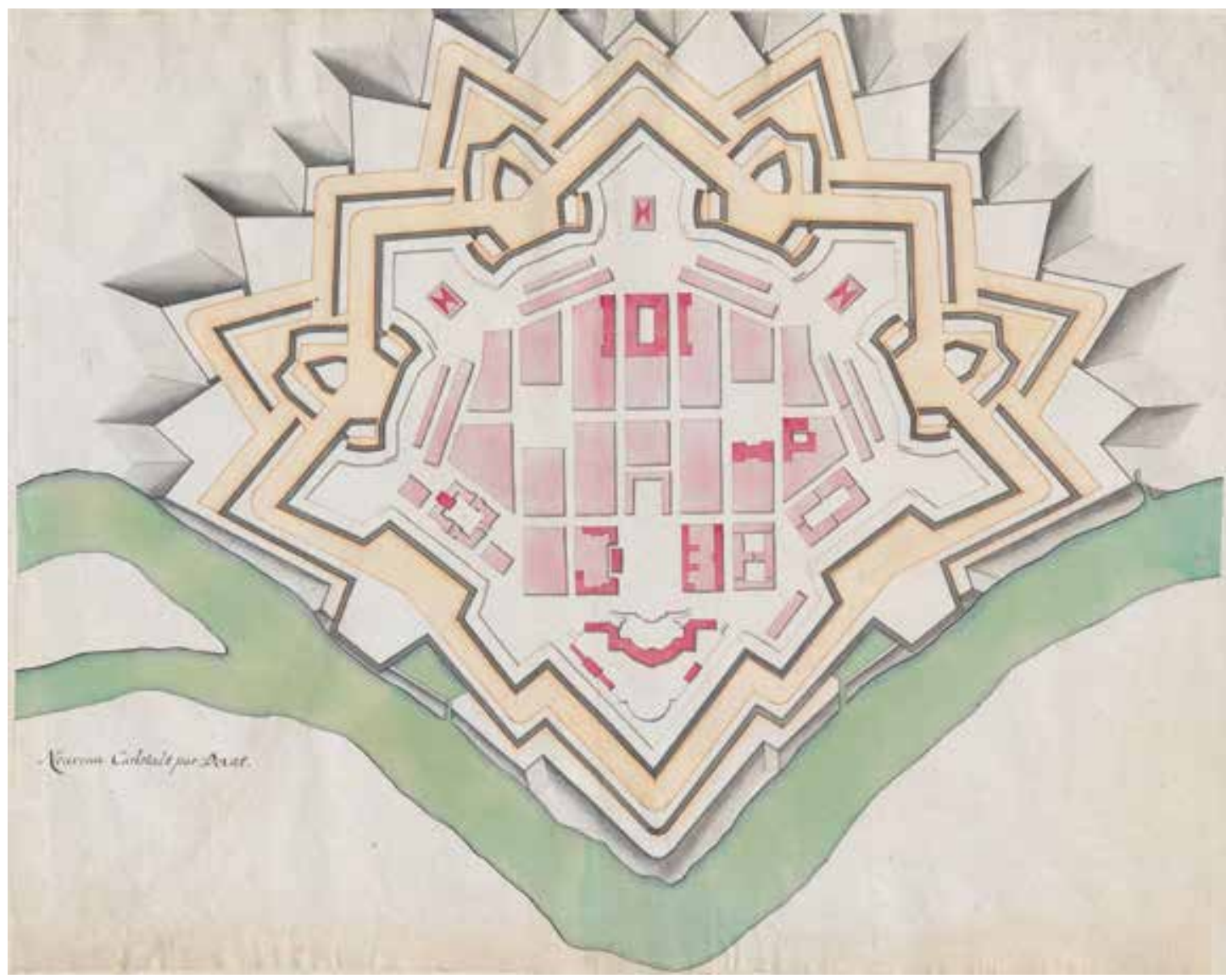

4. Novi Karlovac, prva varijanta projekta grada-tvrđave (Stuttgart, Württembergische Landesbibliothek, Sammlung Nicolai, sv. 104, 33r)

Novi Karlovac, the first version of the town-fortress project (Stuttgart, Württembergische Landesbibliothek, Sammlung Nicolai, sv. 104, 33r)

njeg bastiona prema oštrom zavoju rijeke. Paralelno s njom postavljeno je šest gradskih ulica okomitih na rijeku, a tri su poprečne. Dok su okomite ulice u istim međusobnim razmacima, pa je i širina blokova između njih jednaka (osim rubnih blokova koji su formirani u skladu s polukružnom formom fortifikacijskog okvira), tri poprečne ulice smještene su na međusobno različitim razmacima koji se povećavaju u skladu sa širenjem lepeze, pa se tako i dužina tri reda pravokutnih blokova postupno izdužuje na način da je prvi red blokova prema rijeci kraći, a sljedeća dva se izdužuju.

Treća poprečna ulica, najudaljenija od rijeke, koja je usmjerena prema središtima kurtina između prvih bastiona, najduža je gradska ulica i vjerojatno bi imala posebnu ulogu osobito ako je bilo zamišljeno da na njenim krajevima stoje gradska vrata (što međutim na planu nije naznačeno). $\mathrm{Na}$ njoj su simetrično na glavnu os postavljena dva kvadratna trga, koji su svojom veličinom tek nešto manji od izvorno također kvadratnoga glavnog trga "starog" Karlovca. Iako istih dimenzija, namjena im je određena različito. Istočni trg $^{5}$ ima na uglu s poprečnom ulicom smještenu crkvu i samostan, te još jednu javnu građevinu na južnoj strani, dok na zapadnom trgu nema javnih građevina. Umjesto na trgu, druga predviđena crkva u gradu smještena je na rubnom položaju, u uglu grada uz prvu uzvodnu kurtinu prema platformi uz rijeku, uklopljena u zasebni blok kakav je predviđen simetrično i na nizvodnoj kurtini.

U središnjoj osi, nasuprot središnjem bastionu smještene su u vrhu središnjih blokova javne građevine, vjerojatno vojne namjene, $s$ četverokrilnom građevinom nalik na oružanu (arsenal) $\mathrm{u}$ središtu. ${ }^{6}$ One zajedno $\mathrm{s}$ redom tipskih prizemnih vojarni smještenih u polukrugu nasuprot kurtinama te s barutanama u tri središnja bastiona tvore zasebnu vojnu cjelinu s unutrašnje strane prstena fortifikacija, pri čemu je između oružane i središnjeg bastiona u strogoj simetriji glavne osi formiran svojevrsni vojni trg.

Nasuprot tome, u ishodištu i težištu središnje osi smješten je glavni gradski trg. Na njegovoj sjevernoj strani točka je konstrukcije cijelog projekta grada-tvrđave, konstruiranog iz kružnice od koje je dio točno odmjerenog polukruga pravcem središnje od tri poprečne ulice označen na oba kraja kao ishodište pet bastiona smještenih u polukrugu prema kopnu, dok je dio prema rijeci formiran u trokutu, u skladu s trokutastim oblikom obale rijeke, pri čemu radijus konstrukcijske kružnice dotiče vrh trokuta. Glavni je trg jednake širine kao dva kvadratna trga, no više je nego dvostruko od njih duži. $\mathrm{Na}$ sjevernom je kraju ekstenzija preko poprečne ulice u dvorište građevine s tri krila u širini bloka. Ona nije označena kao javna građevina, a trg obilježavaju takve građevine koje 


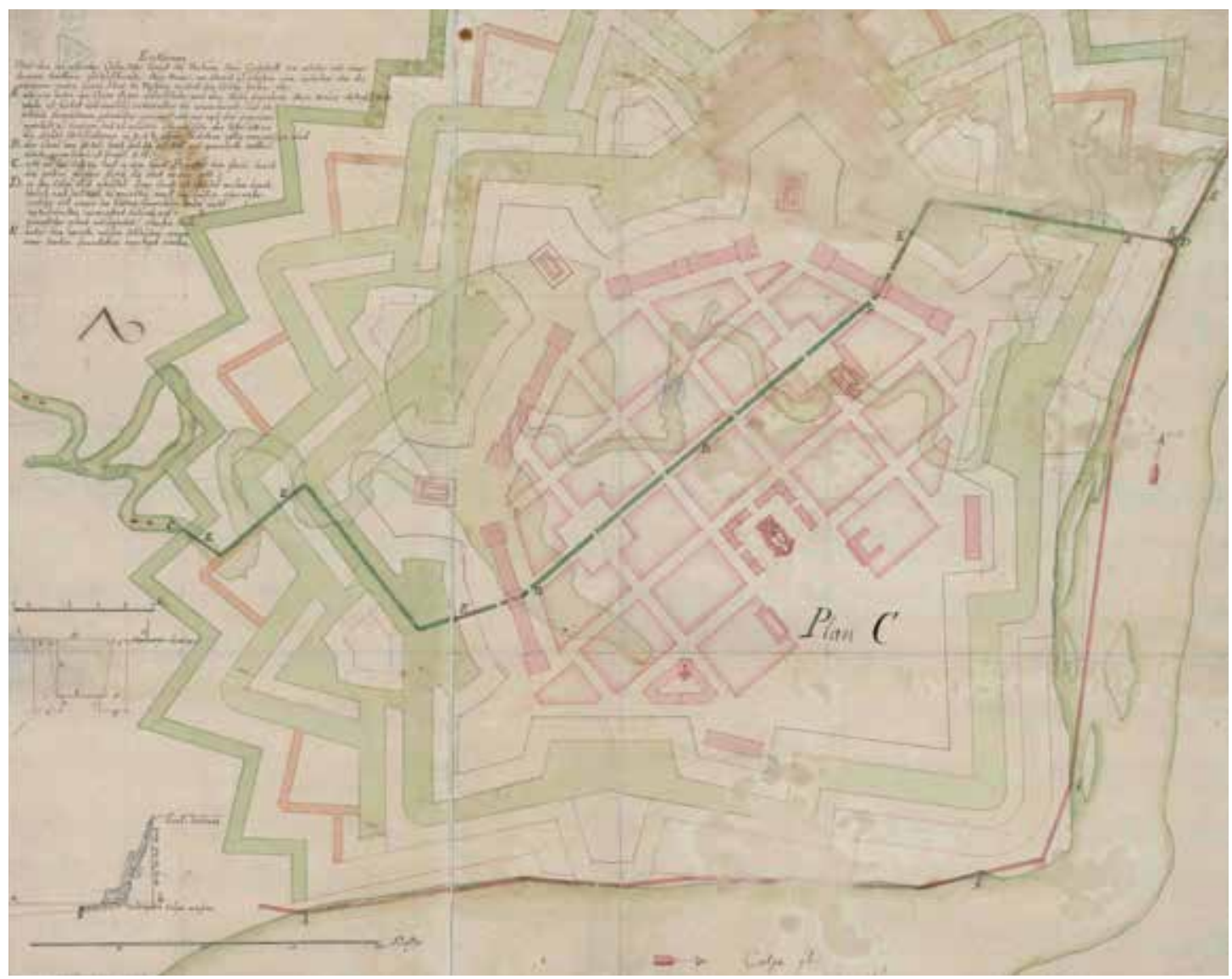

5. Plan C, Neü-Carlstatt (Országos Széchényi Könyvtár, Budapest, TK 1216), tekst (na njemačkom) u gornjem lijevom uglu: Tumač propadajuće obale Kupe duž tvrđave Novi Karlovac, $i$ kako bi je se moglo trajno očuvati usuho gradenim kamenim zidom, također $i$ novoga kanala provučenoga kroz tvrđavu umjesto potoka Orlice: A. kameni zid bez vapna podignut od dna Kupe, profil ab. Vrlo je potreban (s obzirom [?] na rastuće i opadajuće razarajuće plavljenje) da bi se postupno postavilo i podiglo to učvršćenje, u protivnom bi obala za najviše 2-3 godine bila posve odnešena sve do glavne utvrde; B. kanal širok 10 i dubok 12 stopa, zidanih stranica, profil c.d. C. mjesto gdje potok Orlica u kanalu B pod glasijom, kroz šanac, dalje kroz grad na mjestu D. utječe u Kupu. Taj kanal je također neophodno postupno uspostaviti, kako bi česta kiša (koja se zbog čvrstog glinovitog tla ne može upiti i zbog toga uzrokuje mnogo močvarnog tla) mogla otjecati; E. podno ovih bedema treba načiniti ustave, zbog visokog plavljenja.

Plan C, Neü-Carlstatt (Országos Széchényi Könyvtár, Budapest, TK 1216), text in German, in the upper left corner:

Ercklärung über den einreissenden Culpa-Ufer längst der Vestung Neü-Carlstatt, wie solcher mit einer dagegen trockener aufzuführender Stein-Mauer, vor allezeit zu erhalten wäre, ingleichen über den gezogenen neüen Canal, durch die Vestung anstatt des Orliza bachs, als A. ein von boden des Culpa flusses aufgeführte, und ohne Kalch gemauerte Stein-Mauer ut Profil a.b. solche ist höchst nothwendig (sintemahlen die anwachsende, und abfallende Inundationen jedesmahlen einreissen) nach und nach dise angewisene gegenhalt zu fundiren, und zu erhöchen, widrigen fals das Ufer, bis an die Haubt-fortificationen in 2. à 3. jahren höchstens, völlig weggerissen wird B. der Canal von 10. Sch. breit und 12. Sch. tief, mit gemauerte seithen wände eingefassen ut Profil c.d. C. orth wo der Orliza-bach in dem Canal B unter dem glacis, durch die gräben, fehrner durch die Statt an den orth D. in den Culpa fluss einfallet: diser Canal ist gleicher massen unentbärlich nach und nach zu errichten, damit das häuffige regenwasser (welches sich wegen des harten Leimichten boden nicht einzuträncken vermag und dadurch viel sumpfigter grund verursachet) ablauffen kann. E. unter dise Wercke müssen Schleüssen, wegen einer hochen Inundation angeleget werden.

obuhvaćaju veći dio blokova, formirajući bočne strane trga (od kojih bi izdvojena manja građevina na zapadnoj strani možda mogla biti zamišljena kao gradska vijećnica).

Međutim, najvažnija i najzanimljivija među njima je ona što zauzima najprominentniji položaj, u središnjoj osi na strani prema rijeci; to je ujedno reprezentativna pozicija što zatvara trg s južne strane. Osobitost je građevine što je ona tipološki posve strana uobičajenom okruženju grada-tvrđave. Na takvim mjestima je uobičajeno, vidjeli smo, očekivati trijezno koncipirane građevine, poput zatvorenih sklopova s unutarnjim dvorištem, ali ovdje u potpunom kontrastu nalazimo građevinu nekoga drugog registra, kao strano tijelo koje je tu uvedeno da dâ neki novi ton, i da organizam u cjelini učini složenijim. Na očito povišenoj plohi stoji građevina nalik dvorcu, raskošne barokne dispozicije: središnji volumen je konkavno otvoren prema trgu, a u glavnoj osi stoji kontrapunkt u obliku eliptoidnoga središnjeg prostora, srodno dvorcu princa Eugena Savojskog u Ráckeveu Johanna Lucasa von Hildebrandta. Na konkavno se krilo nastavljaju bočno dva kratka okomita krila - s pažljivo zaobljenim prednjim uglovima - a na njih sprijeda još dva uzdužna krila. U cjelini razigrana visokobarokna struktura, raširena u prostoru i s nesumnjivim sceničnim efektom.

Kako je rečeno, građevina je postavljena na povišenu terasu i tu se izmjenjuju konkavne i konveksne forme, stupajući u određeni dijalog s volumenima zgrade. Na terasu s boka vode 


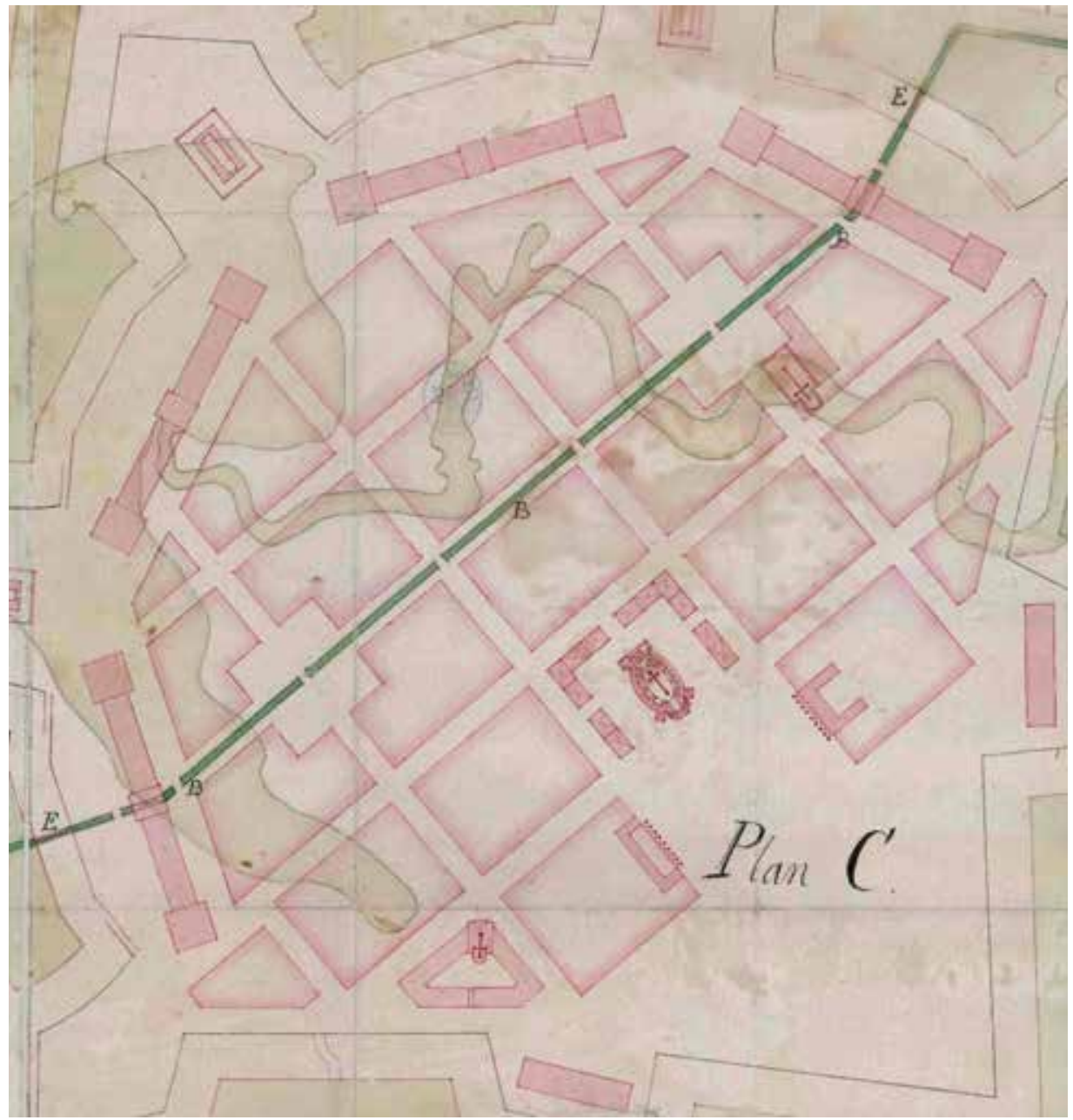

6. Plan C, Neü-Carlstatt, detalj

Plan C, Neü-Carlstatt, detail

dvije reprezentativne rampe, a još dvije jednostavne služe usponu na stražnju terasu. Ta prostrana terasa zaključena je pak velikom polukružnom plohom uza sam vrh osnovnog tijela tvrđave. U bočnom pogledu građevina je postavljena točno u os ušća Korane, pa bi svojim krovištem s kupolom ili visokim "prelomljenim" mansardnim krovom nad središnjom ovalnom jezgrom, kao najviša točka grada dominirala slično onako kako i u dvorcu u Ráckeveu dominira s plovnog rukavca Dunava.

Ansambl u svakom pogledu potvrđuje svoju ulogu najvažnije građevine u tvrđavi: ne nalazi se, doduše, u njezinu prostornom središtu, ali stoji na, moglo bi se reći, najsigurnijemu mjestu. Drugi je aspekt zahtjevnost njezina oblikovanja, kojom očigledno odskače od svih ostalih zgrada, i time nosi simboličnu poruku svoga prvenstva. Dakako, postavlja se pitanje o planiranoj funkciji te zgrade u projektantovoj viziji, a koja se morala temeljiti na određenom programu. I bez daljnjih podataka o ovom projektu, može se sa sigurnošću reći da je riječ bila o sjedištu zapovjednika, i to ne samo Karlovca, nego i Karlovačkoga generalata. No ta nekonvencionalna zamisao ipak ne bi bila doživjela izvedbu čak i da je tvrđava bila izgrađena, kako to pokazuju nacrti koji slijede.
Među nacrtima što se čuvaju u Budimpešti, a koji dokumentiraju proces gradnje Novog Karlovca u 1733. i 1734. godini najvažniji je nacrt označen kao Plan C (sl. 5). On donosi dva dodatna projektna rješenja koja su objašnjena tekstom na samom nacrtu: rješenje za učvršćenje obale Kupe te projekt kanaliziranja potoka Orlica kanalom provedenim kroz grad sredinom kvadratnih trgova i ulice koja ih spaja. Te su dopune, međutim, donesene na cjelovitom prikazu projekta novoga grada koji uz manje razlike u rješenju fortifikacija pokazuje bitne razlike u rješenju urbane strukture u odnosu na ono vidljivo na prikazu iz Stuttgarta. Fortifikacije su dopunjene dodatnim vanjskim kanalom koji prati rub (znatno skraćene) glasije. Osim što je njime riješen problem odvodnje, fortifikacijski pojas dobio je tako i svoj treći (a pred kurtinama čak četvrti!) obrambeni opkop. Na izvještajnom nacrtu označenom kao Plan A (sl. 9) obilježena su i imena određena za bastione. Središnji Karlov bastion posvećen je caru i kralju Karlu VI., Eugenov bastion s njegove desne (istočne) strane princu Eugenu Savojskom, a s lijeve Franjin bastion Franji Stjepanu von Lothringenu, carevu budućem zetu i nasljedniku, koji je 1732. postavljen na mjesto »locumtenensa « Ugarskoga Kraljevstva. Dva bočna i nešto 
manja bastiona do Kupe posvećena su pak ugarskim svetim kraljevima Stjepanu i Emeriku. ${ }^{7}$

U konačno prihvaćenom projektu grada, kao što je to vidljivo na Planu C (sl. 6), ulična struktura riješena je u odnosu na ideje iz prvog nacrta jednostavnije i kompaktnije. Iako broj ulica koje se protežu paralelno sa središnjom osi također iznosi šest, kao i u prvoj verziji, dvije rubne ulice određuju samo rub po jednog bloka u drugom redu od Kupe, pa zapravo četiri ulice prolaze cijelom dužinom, protežući se do ophodnog prstena. Umjesto tri planirane poprečne ulice u prvoj verziji, sada su poprečno usmjerene četiri ulice. Tako uspostavljena mreža određuje ujednačenije dimenzije pravokutnih blokova, koji se međutim dužim stranicama protežu u poprečnom pravcu, suprotno pravcu protezanja u prvoj verziji projekta. ${ }^{8}$

Urbanistička ideja s dva kvadratna trga simetrično raspoređena u odnosu na centralnu os zadržana je, ali su trgovi u novoj verziji formirani izostavljanjem uglova četiriju okolnih blokova na način kako je to Vincenzo Scamozzi zamislio u svom prijedlogu grada-tvrđave 1615 . godine, ${ }^{9}$ a ne skraćivanjem po dva bloka kao u prvoj verziji, pa tako i ulice paralelne s glavnom osi, kao i njima poprečne ulice prolaze središtem trgova. Na sjeveroistočnom trgu crkva više nije smještena uz poprečnu ulicu, nego uz njoj okomitu, formirajući sa samostanskim krilom (ili samo župnom kućom?) ugao trga. Zadržana je i izvorna ideja da drugi kvadratni trg nema javnih sadržaja te da je druga crkva sa samostanskim sklopom smještena rubno u posebnom bloku blizu Kupe, što je u novom projektu riješeno domišljenije položajem omanje crkve uklopljene u zaseban trokutasti blok i usmjerene $\mathrm{u}$ dijagonalu uličnog križanja, gdje dimenzije crkve ukazuju na mogućnost da nije riječ o samostanu, nego možda o vojnoj bolnici s kapelom. Urbanističku vrijednost kvadratnih trgova, kao i ulice koja ih spaja, bitno je obogatilo dodavanje kanaliziranog potoka Orlice u prolazu njihovim središtem, sa slikovitim mostovima u sredini trgova i u osi ulica, te prolazom kroz vojarne na krajevima ulice, što je kao posve nizozemsko rješenje ostalo jedinstveno te vrste u hrvatskoj urbanističkoj baštini baroknog razdoblja. ${ }^{10}$

Smještaj vojarni uz bedeme, s četirima golemim vojarnama prema kurtinama, te dvjema manjima na platformama prema Kupi zadržan je, ali ne i ideja o posebnom vojnom trgu prema središnjemu carskom bastionu. Umjesto toga, karakterističnim tipskim vojarnama povećane su dimenzije i u cjelini su bolje i jednostavnije povezane s bastionima, formirajući čvrst okvir rubne polukružne ulice.

Najveću promjenu doživjela je koncepcija glavnoga gradskog trga. Prije svega, odbačena je ideja o dvorcu kao dominantnoj građevini koja zatvara trg prema rijeci. Njezinim izostavljanjem trg je ostao na toj strani posve otvoren prema golemomu praznom prostoru trokutastog vrha bedema prema Kupi, pri čemu je sam trg formiran izostavljanjem po jednoga središnjeg bloka prvoga i drugog reda prema rijeci, smještenih u osi simetrije koju određuje pravac od vrha trokuta bedema uz obalu rijeke do vrha Karlova bastiona na suprotnoj strani prema kopnu. Prostor trga nastao izostavljanjem središnjeg bloka u prvom redu, s obje bočne strane flankiraju dvije istaknute javne građevine, čija je važnost posebno naglašena i naznakom reda stupova trijema pred njihovim pročeljima. Za razliku od javnih zgrada uz trg u prvoj varijanti projekta, koje su obuhvaćale veći dio cijelih blokova, one su sada primjerenije dimenzionirane te ne zauzimaju ni cijele dužine pročelja bočnih blokova prema trgu. Simetrično postavljene u odnosu na trg, vjerojatno su bile planirane kao sjedišta s jedne strane vojne, a s druge strane građanske vlasti.

Trgom, kao i cijelim gradom u usvojenoj verziji projekta umjesto prvobitno zamišljenog dvorca dominira svojim istaknutim položajem, ali i arhitekturom izuzetna crkvena građevina smještena u središtu drugoga "izostavljenog” bloka u središnjoj osi trga i cijeloga grada. Njezin začelni zid, zid svetišta crkve, stoji i neposredno uz točku konstrukcije velike kružnice temeljem koje su uspostavljene dimenzije i konstruiran tlocrt grada, a koja se u prvoj verziji nalazila na sjevernom rubu trga u sjecištu najduže poprečne ulice i središnje osi simetrije. Sada je pomaknuta malo povučenije od ruba najduže poprečne ulice, koja flankira trg sa sjeverozapadne strane, a na krajevima završava u prvim bastionima do Kupe. Njoj paralelna poprečna ulica koja dijeli trg na dva različita dijela, uz koju crkva stoji neposredno svojim pročeljem, glavna je gradska ulica, jer se na njenim krajevima nalaze jedina dva ulaza u utvrđeni grad kroz prolaze u kurtinama okrenutima rijeci, kao što je to naznačeno na izvještajnim nacrtima (Plan A, sl. 9 i Plan B, sl. 10) s mostovima preko opkopa uz Kupu.

Crkva je s triju strana okružena nekim javnim građevinama koje očito zbog svoga centralnog položaja u gradu imaju važnu ulogu, no namjena im na nacrtu nije naznačena. Ukupno dvanaest tipskih građevina naslonjenih jedna na drugu postavljeno je tako da ponavljaju okvir bloka, ostavljajući prolaze po sredini na tri strane, a punu otvorenost prema središnjoj plohi trga, gdje uokviruju prostornu dominaciju crkve prema toj strani.

Crkva je građevina eliptoidnog tlocrta, kojim se posve jasno referira na bečku Peterskirche, crkvu koja je upravo u to vrijeme, 1732. bila dovršena prema projektu Johanna Lucasa von Hildebrandta, i posvećena 1733. godine, izazivajući veliku pozornost i oduševljenje svojom arhitekturom kao prva crkva s kupolom u Beču. Središnja planirana crkva u Novom Karlovcu koja je na prikazu grada iz 1734. prikazana u tlocrtu, svojom dužinom od približno 47 metara tek za oko sedam metara zaostaje za dužinom bečke crkve. Ako je na prikazu grada njezin tlocrt točno prenesen, ona ne predstavlja izravnu kopiju bečke crkve, nego varijaciju tlocrta, posebno u zoni svetišta i u bočnim kapelama (sl. 7), pa je malo vjerojatno da je riječ tek o osobnom prijedlogu projektanta cijeloga grada Nicolasa Doxata de Démoreta. Gradnju grada, kao i u drugim slučajevima, izravno je nadzirao princ Eugen Savojski kao predsjednik Dvorskoga ratnog vijeća, pa je zasigurno nakon promjene koncepcije, što je bio rezultat kritičkog razmatranja svih pojedinosti i potom bliskog praćenja realizacije, izravni angažman prinčeva arhitekta Johanna Lucasa von Hildebrandta u projektu nove crkve, glavne crkve u velikome novom carskom gradu-tvrđavi, puno vjerojatniji. 

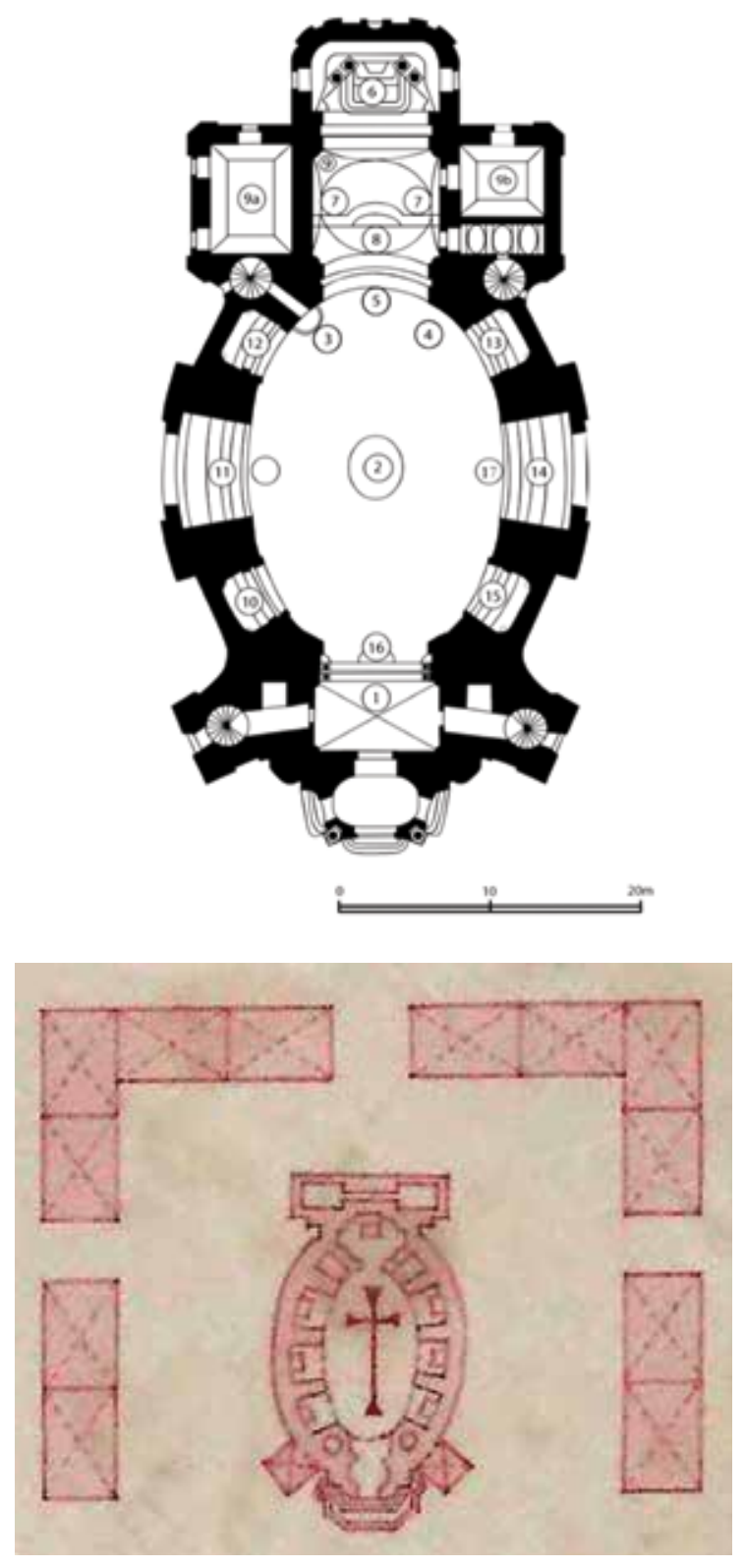

7.a Peterskirche u Beču, dovršena 1732. - 1733. prema projektu Johanna Lucasa von Hildebrandta Peterskirche in Vienna, completed 1732-1733 according to the project of Johann Lucas von Hildebrandt

7.b Projekt središnje crkve Novog Karlovca 1734. (dužina Peterskirche iznosi oko 55 m, a planirane crkve u Novom Karlovcu prema tlocrtu na planu grada oko $48 \mathrm{~m}$ )

Project of the central church of Novi Karlovac in 1734 (the length of the Peterskirche is about 55 m, while the planned church in Novi Karlovac was to be about $48 \mathrm{~m}$ long according to the ground plan in the town map)

Svojom kupolom crkva bi bila i osobita visinska dominanta, nasljeđujući i zamjenjujući na određeni način prvu ideju s eliptoidnim središtem, također hildebrandtske arhitekture prvobitno zamišljenog dvorca uz Kupu.

Godina 1734. u kojoj su izrađeni izvještajni planovi (sl. 8, 9, 10) postala je, međutim, iznenada posljednja godina gradnje novoga grada. Te godine započeo je novi rat s Francuskom, Rat za nasljedstvo Poljske krune (1734. - 1735.), koji će se za Carstvo pokazati katastrofalnim, obilježivši teškim porazima posljednje godine vladavine cara i kralja Karla VI.
Princ Eugen Savojski, koji je prešavši sedamdesetu godinu života i dalje bio predsjednik Dvorskoga ratnog vijeća i zapovjednik vojske, više nije imao snage da vodi novi rat na bojnom polju, pa ni izvan njega. Pasivnu obranu vodio je u proljeće 1734. na Rajni, a u Beč se vraća krajem godine vrlo bolestan, kada u studenome doživljava novi udarac smrću svoga posljednjeg muškog nasljednika nećaka Eugena. Pa ipak i iduću godinu provodi na Rajni gdje još samo njegovo ime sprječava Francuze u izravnijoj ofenzivi, no 20. travnja 1736. princ Eugen Savojski umire u Beču. U ratu koji je 
potom uslijedio i s Osmanskim Carstvom stradat će 1738. nepravednom osudom na smrt, ostavši bez prinčeve zaštite, glavni projektant njegovih gradova-tvrđava, projektant Novog Karlovca Nicolas Doxat de Démoret. Nakon velikih poraza, sklapanja novoga mirovnog ugovora s Osmanskim Carstvom 1739. i najzad smrti cara i kralja Karla VI. 1740. godine, okolnosti su se radikalno izmijenile, a nova carica Marija Terezija morala je odmah voditi nove ratove s Pruskom. Kada je nakon stabilizacije svoje vladavine nastavila s gradnjom tvrđava, u posve novim povijesnim okolnostima podizanje velikoga novoga grada-tvrđave pored Karlovca više nije imalo istu stratešku važnost, pa su u drugoj polovini 18. stoljeća umjesto nastavka radova samo neznatno modernizirane zemljane fortifikacije starog Karlovca.

Da stari grad-tvrđava Karlovac više nije mogao biti pogodan za obranu u doba kada je razvoj vatrenog oružja, posebno topništva, daleko odmakao, utvrdila je carska komisija 1721. godine, zaključivši »da bi bilo skoro jednostavnije sagraditi novu negoli od ove stare napraviti onakvu kakva bi trebala biti ratna tvrđava 18. stoljeća «. ${ }^{11}$ Taj je zaključak donesen u vrijeme kada je Dvorsko ratno vijeće pod predsjedanjem princa Eugena Savojskog najintenzivnije pokretalo i vodilo gradnju golemoga novog strateškog sustava gradova-tvrđava prema poraženom Osmanskom Carstvu, s kojim je 1718. sklopljen povoljan mirovni sporazum u Požarevcu. Taj je sustav novoplaniranih baroknih gradova-tvrđava bio najveći graditeljski pothvat Habsburške Monarhije i novo cjelovito poglavlje u razvoju baroknih fortifikacija. Protezao se od Transilvanije na istoku, a Karlovac je bio njegova najzapadnija sastavnica. Obuhvaćao je petnaestak gradova-tvrđava, uglavnom starih povijesnih gradova smještenih na ključnim strateškim mjestima. ${ }^{12}$ Gotovo svi su oni u vrijeme osmanske vlasti doživjeli karakterističnu preobrazbu u duhu orijentalne gradogradnje (a jedino je Karlovac bio u tom smislu iznimka jer nikada nije bio osvojen), pa su uz gradnju novih suvremenih fortifikacija istovremeno i njihove urbane strukture uglavnom radikalno preoblikovane u nove barokne gradove.

Od 1722. vodstvo nad projektiranjem i gradnjom cijelog sustava preuzeo je Nicolas Doxat de Démoret, podrijetlom Švicarac, školovan u nizozemskoj fortifikacijskoj školi, koji je dotad tri godine vodio projektiranje fortifikacija u Temišvarskom Banatu. Postavši “austrijskim Vaubanom”, glavnim projektantom tvrđava princa Eugena Savojskoga, Nicolas Doxat je u jedva petnaestak godina intenzivne aktivnosti ostvario golem opus koji ga stavlja na mjesto glavnog nasljednika dvojice velikih fortifikacijskih inženjera prije njega, Sébastiena de Vaubana i Mennoa van Coehoorna. Za razliku od njih, Nicolas Doxat iskazao se i kao vrsni barokni urbanist, o čemu svjedoče i oba njegova projekta Novog Karlovca.
Nakon što je u gradnji od početka jedinstveno planirane cjeline najveća pažnja najprije bila posvećena projektiranju i izgradnji najvažnijih gradova-tvrđava na ključnim mjestima u središtu sustava, prvenstveno na strateški prioritetnom Dunavskom pravcu, već od 1725. Dvorsko ratno vijeće posvetilo se i izgradnji zapadnoga krila. Za zapovjednika Slavonskoga generalata u Osijeku princ Eugen je 1724. postavio generala Johna Josepha O'Dwyera, kako bi intenzivirao i organizirao radove u Osijeku i drugim tvrđavama Generalata, koje su (uz, dodatno, Karlovac na krajnjem zapadu) tvorile zapadno krilo. O’Dwyer je 1725. potaknuo gradnju Stare Gradiške, a Nicolas Doxat je, nakon upoznavanja postojeće nove tvrđave u Slavonskom Brodu, od 1726. osobno preuzeo izradu najvažnijih projekata. Iduće godine usvojen je njegov novi projekt za tvrđavu Brod, a 1728. izveo je projekt modernizacije osječkih fortifikacija, te u rujnu iste godine i projekt za novi grad-tvrđavu Rača (Srijemska Rača) nasuprot ušću Drine u Savu. Nakon analize Karlovca 1729. godine, kojom je potvrdio nemogućnost njegove modernizacije, složio se s ranijim prijedlozima za izgradnju posve novoga grada-tvrđave, vjerojatno osobno odabravši njegovu lokaciju nasuprot ušću Korane u Kupu.

Projekti Nicolasa Doxata za dva nova velika grada-tvrđave Raču i Novi Karlovac, izrađeni 1728. i 1729. godine, posjedovali su, sudeći po jednom shematskom prikazu dosad nedovoljno istraženih projekata Rače, neke izrazite koncepcijske, kao i oblikovne srodnosti, posebno u naglašenoj jednoosnoj simetričnosti cjeline, kakvu ne pokazuju drugi njegovi projekti. Prva verzija projekta Novog Karlovca, koju u kopiji vidimo na nacrtu u Stuttgartu, potječe vjerojatno iz 1729. godine. Iduće godine Doxat je zatražio od princa Eugena umirovljenje, premoren radnim ritmom i obvezama, $u$ namjeri da se povuče na svoj obiteljski posjed Démoret kod Yverdona u Švicarskoj, no princ Eugen mu to nije dopustio, nego je od cara i kralja Karla isposlovao njegovo unapređenje u generalmajora. Te godine započeo je otkup zemljišta za novi grad-tvrđavu kod Karlovca, a podignute su i peći za vapno i opeke. ${ }^{13}$ Gradnja je, kao što smo vidjeli, intenzivirana najzad 1733. i 1734. godine, ali prema izmijenjenome urbanističkom planu unutar započetih bedema, a potom je prekinuta početkom novog rata i posve zaustavljena nakon smrti princa Eugena Savojskoga.

Ovaj neobični slučaj u povijesti gradogradnje, međutim, zavrjeđuje punu pažnju u svim svojim aspektima. Veliki novi barokni grad, koji se počeo graditi 1733. na lijevoj obali Kupe nedaleko od Karlovca, bio bi, da je njegova gradnja nastavljena, jedan od najvećih, a svakako i urbanistički najzanimljivijih gradova u Hrvatskoj, na što podsjećaju do danas očuvani ostatci njegovih započetih zemljanih bedema, ali i nacrti grada, koji predstavljaju osobiti dio urbanističke baštine baroknog razdoblja u Hrvatskoj. 


\section{PRILOG}

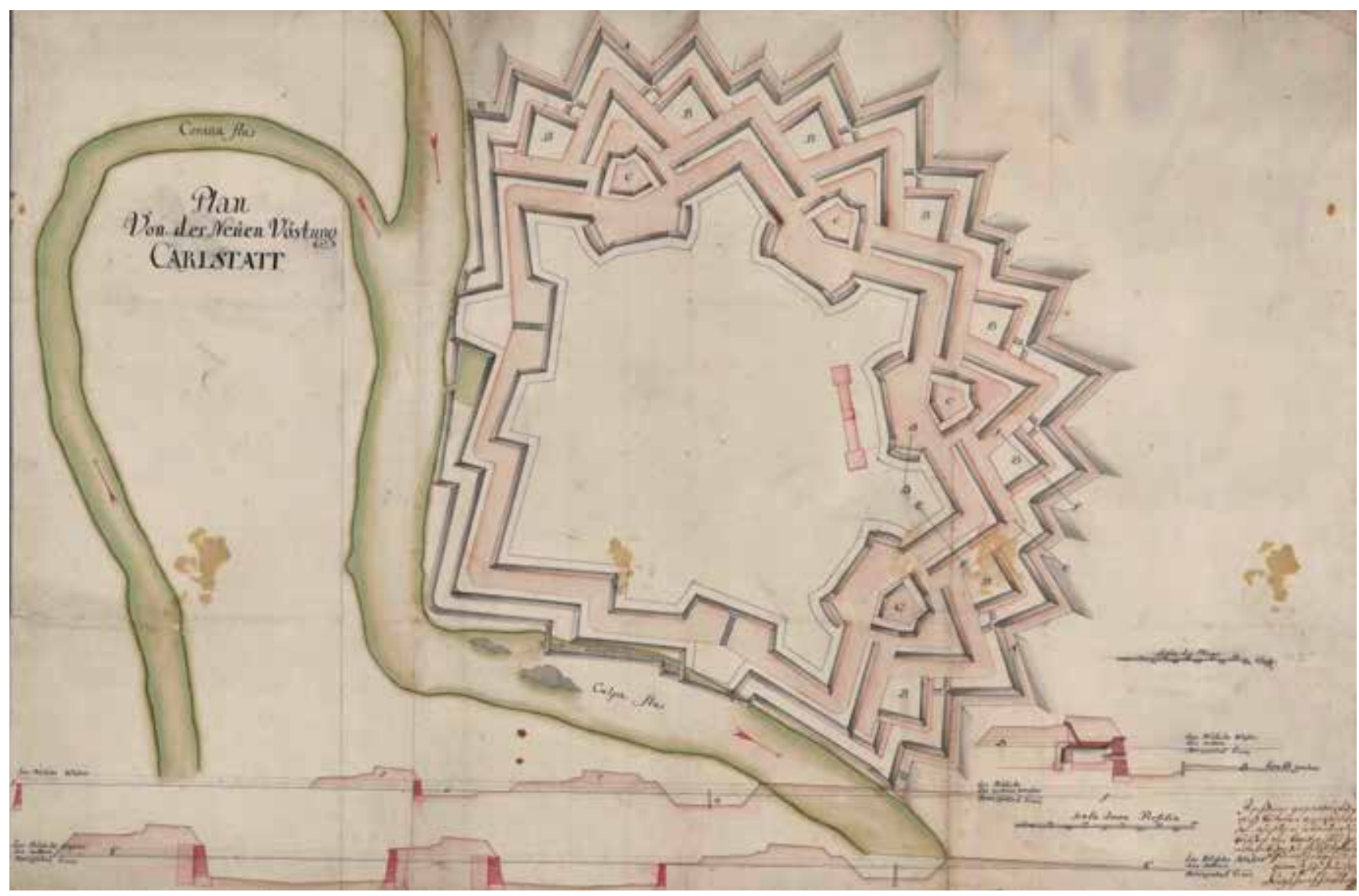

8. Plan von der Neüen Vöstung Carlstatt, 1734. (Országos Széchényi Könyvtár, Budimpešta, TK 2085). Projekt bastionske trase s presjecima; mostovi preko opkopa uz Kupu pokazuju položaje gradskih vrata.

Plan von der Neüen Vöstung Carlstatt, 1734 (Országos Széchényi Könyvtár, Budapest, TK 2085). Bastion trace project with cross-sections; bridges over the moat along the river Kupa show the positions of the town gates. 


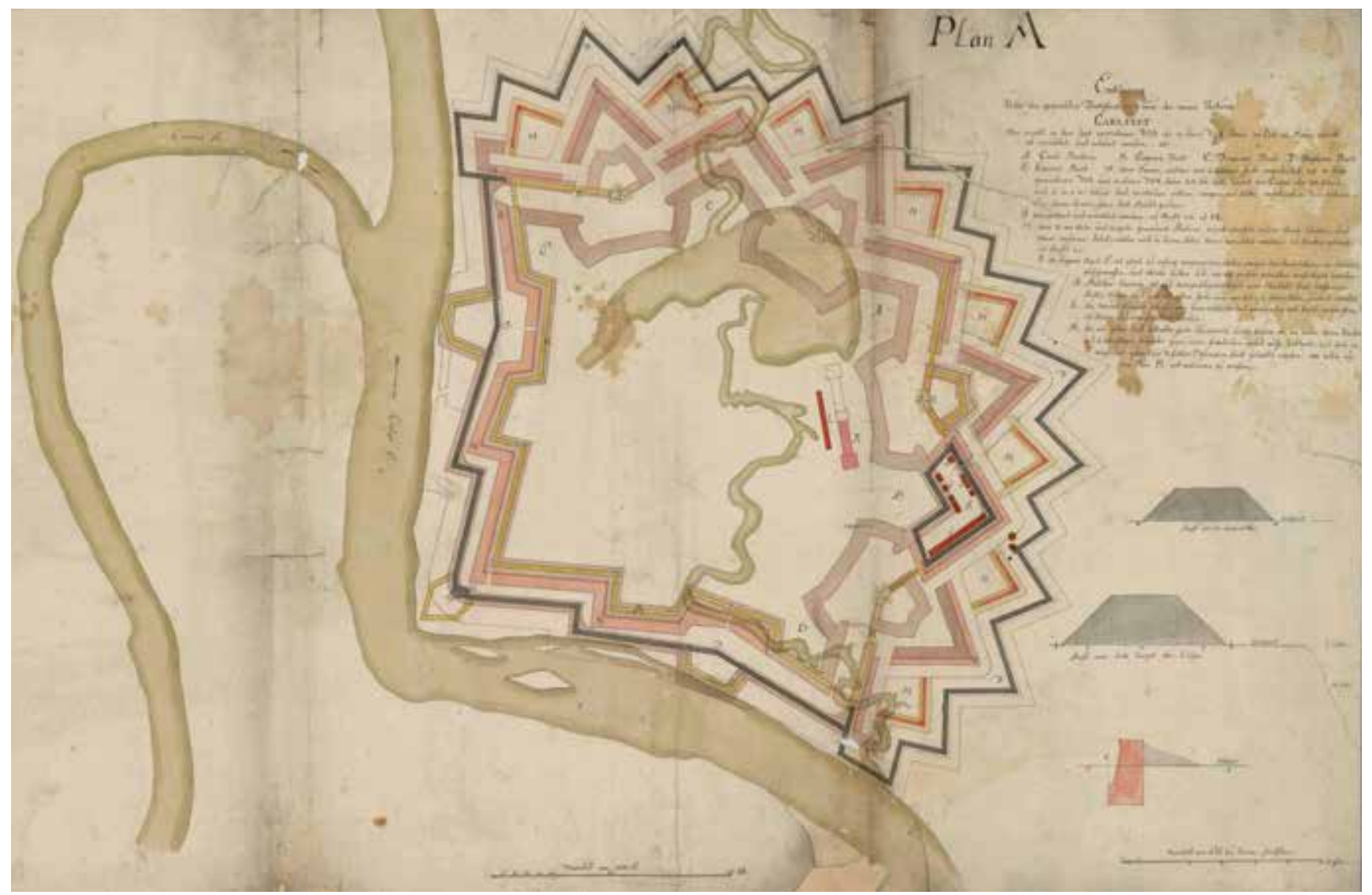

9. Plan A, izvještajni plan o radovima 1733. i 1734. s imenima bastiona (Országos Széchényi Könyvtár, Budimpešta, TK 2098), tekst (na njemačkom) u gornjem desnom uglu:

Tumač cijele gradnje nove tvrđave Karlovac. Što je kako prethodne 1733. tako i ove 1734. godine podignuto i izgradeno od zemljanih $i$ zidarskih radova. A. Karlov bastion, B. Eugenov bastion, C. Franjin bastion, D. Stjepanov bastion, E. Emerikov bastion; F. ovaj bedem, označen crno, prethodne 1733. i ove 1734. godine širok je 24 stope, uz Kupu međutim 30 stopa, i 6.10 do 15 [?] stopa visok, na nizu mjesta, zbog svakogodišnjeg plavljenja na Couvre-face i glavnom opkopu; G. naveženo i podignuto, profil aa i bb; $H$. ovih 8 kamenom i opekom zidanih redana također je uređeno, osim njihovog kordona i djelomično vanjskog taluda [? talusa] (koji bi se još ove godine mogao podići), profil cc; I. u Eugenovu bastionu E je odmah početkom prošle godine zbog plavljenja nasipan bedem i besplatni radnici podignuli su niz koliba dd; K. vojnoj kasarni je na temelju visokomilostive zapovijedi preslavnog carskog Dvorskog ratnog vijeća ove godine izvedena polovica temelja (označeno crveno); L. zidarska kasarna, samo od glinovite zemlje, iznutra i izvana okrečena, podignuta je ove godine; M. žute i svijetložute linije označavaju što bi se ove zime i sljedećeg proljeća moglo urediti protiv neprijateljskog napada, najlakše a ipak u obliku trostruke zaštite. Što se točnije može vidjeti na planu B. Plan A, report on the works in 1733 and 1734 with the names of the bastions (Országos Széchényi Könyvtár, Budapest, TK 2098), text in German in the upper right corner:

Ercklärung über den gesambten Fortifications-bau der neuen Vestung Carlstat was sowohl in dem lezt verwichenen '733. als in disen '734. Jahre an Erd- als Mauer-arbeith ist errichtet, und erbauet worden als A. Caroli Bastion B. Eugenÿ Bast. C. Francisci Bast. D. Stephani Bast. E. Emerici Bast. F. diser Damm, welcher mit schwarzer farbe angedeütet, ist in dem verwichenen '733. und in disem '734. Jahre 24 Sch. dick, längst der Culpa aber 30 Schuch und 6. 10 à 15 Schuch hoch, an etlichen orthen, wegen der Jährl. einfallenden Inundation aus denen Couvrefaces und Haubt gräben G. transportiret und errichtet worden ut Profil aa. et bb. H. dise 8. von Stein und Ziegeln gemauerte Redans, seÿnd ebenfals ausser ihren Cordon, und etwas ausseren talud (welches noch in disem Jahre kann errichtet werden) zu Ständen gebracht ut Profil cc. I. im Eugenÿ Bast. E. ist gleich zu anfang vergangenen Jahrs, weegen der Inundation ein Schantz aufgeworffen, und etliche hütten dd. vor die gratis-arbeither verfertiget worden. K. Militar-Caserne, ist auf hochgnädigsten befehl eines Hochlöbl. Kä̈l. Hoffkriegsraths, halben theil (was mit rother farbe angemarcket) in disen Jahre fundiret worden. L. die Mauer Caserne ist nur von Leim-erde, in und auswendig mit Kalch verworffen, in disem Jahr auffgebauet worden. M. die mit gelber und hellgelber farbe illuminirte Linien Zeigen an, wie solche disen Winter und zukünfftigen fruh-jahr gegen einen feindlichen anfall, auffs leichteste, und doch in möglichst gebrachten 3.fachen Defension könte gebracht werden. Wie solche aus dem Plan B. mit mehreren zu ersehen. 


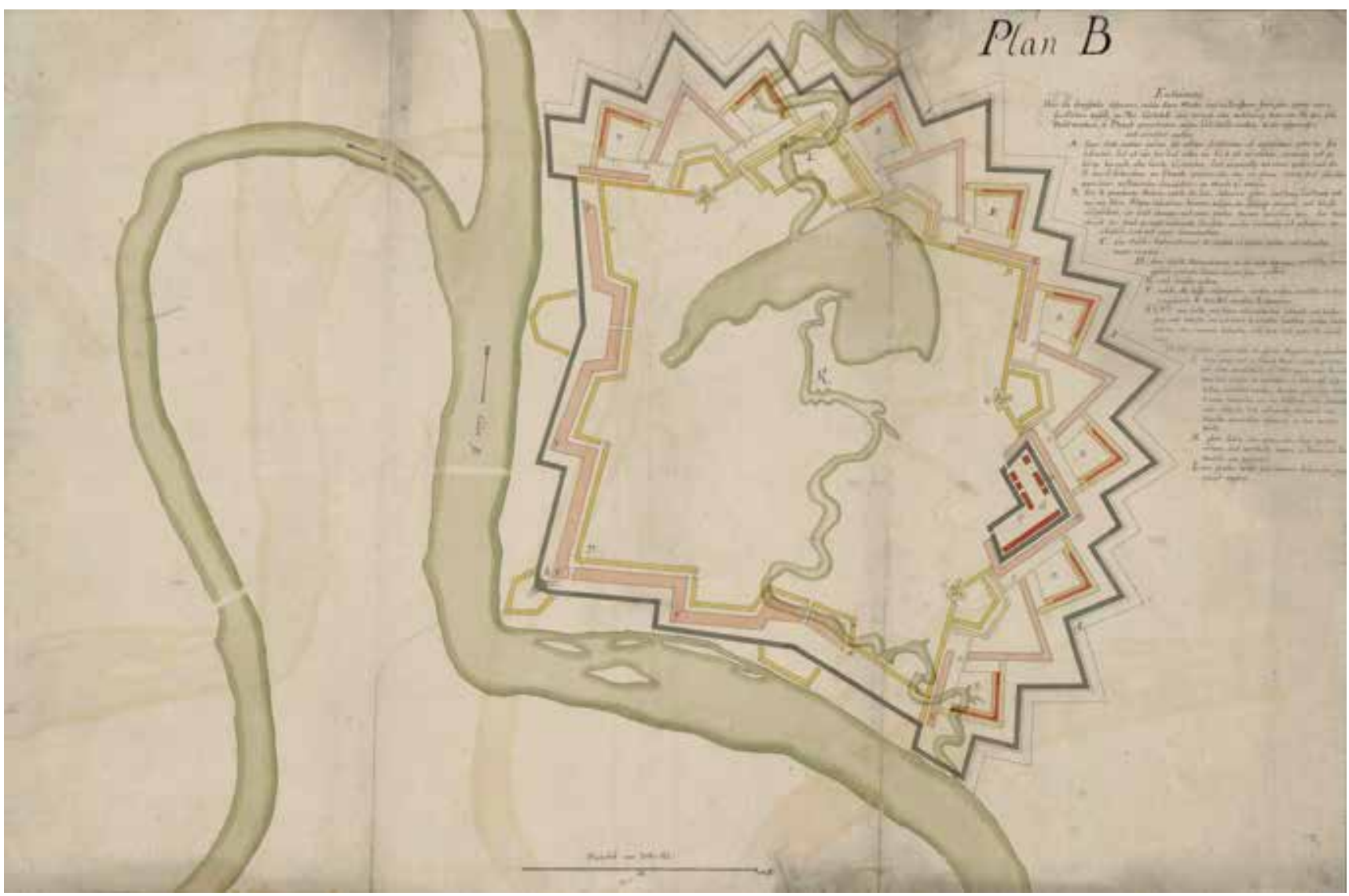

10. Plan B (Országos Széchényi Könyvtár, Budapest, TK 2099), tekst (na njemačkom) u gornjem desnom uglu:

Tumač trostruke zaštite, koja bi se ove zime i sljedećeg proljeća mogla navesti i podići, protiv neprijateljskog napada na Novi Karlovac, a da se ne odustane ili naruši vanjske i glavne bedeme što ih je projektirao generalmajor von Doxat. A. ovaj bedem, podignut uokolo cijele utvrde, stvara prvu zaštitu, $i$ treba ga samo tu i tamo povisiti za 1 do 3 stope, iznutra opremiti primjerenim banketima, a izvana jarkom (prema projektu generalmajora von Doxata) ili glasijom (koja je gotovo otpornija na plavljenje). B. ovim 8 zidanim redanima, koji tvore drugu zaštitu $i$ mogu se dva po dva braniti poput malog poligona, treba dodati odgovarajuće parapete i bankete, kao i jarak pred njima. Kako neprijatelj te redane ne bi napao straga, treba ih jednostrano zaštititi palisadom i komunikacijom C. prema glavnoj zapreci, koja je takoder obostrano opremljena palisadom. D. ovu glavnu zapreku, kao treću zaštitu, treba izvesti uokolo svega, te je načiniti iz jaraka Couvre-face E. i glavnih jaraka F. koje sve treba dublje iskopati. U njezina unutarnja 4 ugla treba izvesti 4 kaponira GGGG od drva, s puškarnicama i sa zemljanim nasipom protiv topova, okružene jarkom širokim 3 klaftera. Ti kaponiri ne pokrivaju samo obje nasuprotne linije HH. već ih se može koristiti i kao barutane; I. ova utvrdica u Eugenovu bastionu, okružena zemljanim bedemom, podignuta je 1733. s kolibama za radnike, zbog plavljenja. S obzirom da u toj utvrdici u slučaju opsade može biti mnogo stvari, vrlo je korisna, i potrebna, i predstavlja jaku unutarnju obranu na unutarnjem prostoru K. dakle sobzirom na tu veliku korist i prednost, moglo bi se u Franjinu bastionu takoder podići utvrdicu L. jednake veličine i za unutarnju obranu.

Plan B (Országos Széchényi Könyvtár, Budapest, TK 2099), text in German in the upper right corner:

Plan B. Ercklärung über die dreyfache defension, welche disen Winter und zukunfftigen fruhjahr, gegen einen feindlichen anfall, an NeüCarlstatt, ohne verwerf- oder verletzung deren von hl. Gen. feldwachtmeistern v Doxat projectirten aussen und Haubt-wercken, Könte aufgeworffen und errichtet werden. A. diser damm, welcher umbher der völligen fortification ist aufgeführet, gibet die 1te defension, und ist nur hin und wider um 1. à 3. Sch. zu erhöhen, einwendig mit gehörige banquets, oder bäncke zu versehen, und auswendig mit einen graben (nach des hl. Gen. F.W.meistern von Doxats project) oder aber en glacis (welche fast stärcker gegen einer ankommenden Inundation) im stande zu setzen. B. dise 8. gemauerte Redans, welche die 2.te defension geben, und zweÿ und zweÿ sich wie eine kleine Polÿgon defendiren können, müssen die gehörige parapets mit bäncke aufgeführet, wie nicht weniger mit einen graben darvor versehen seÿn. Dise Redans (damit der feind sie nicht ruckwerths überfalle, werden einwendig mit pallisaden verschlossen, und mit einer Comunication C. zum HaubtRetranchement, die ebenfals zu beÿden seithen mit pallisaden besezt, versehen. D. dises Haubt-Retranchement, als die dritte defension wird völlig herumgeführt, und aus denen Couvre-face gräben E. und Haubt-gräben F. welche alle tieffer ausgegraben werden müssen, errichtet. In ihre eingehende 4. Winckel, werden 4. Caponiers G.G.G.G. von holtz mit ihren schiesscharten erbauet, mit bombenfreÿ-erde bedeckt, und mit einen 3. Klaffter breithen graben umher versehen. Dise Caponiers bestreichen nicht allein beede gegen über ligende linien H.H. sondern seÿnd auch als pulver-Magazine zu gebrauchen I. dises schäntzel im Eugenÿ Bast., welche mit einen erd-damm umschlossen, ist '733. gegen einer Inundation, und worinne die arbeither in hütten sich aufgehalten, errichtet worden. Imassen nun dises schäzel in einer belagerung vor eine behältnus viller Materialien sehr nutzlich, und nothwendig, also auch eine starcke einwendige defension in dem inneren platz K. gibet. Könnte also gegen über, dises grossen nutzen, und vortheils weegen, in Francisci Bast. ebenfals ein schänzel L. von gleicher grösse und inneren defension angeleget werden. 


\section{Bilješke}

* Rad je nastao u sklopu istraživanja na znanstvenom projektu Eugen Savojski (1663. - 1736.) i gradovi-tvrđave jugoistočne granice Habsburške Monarhije (HRZZ-IP-2018-01-3844), koji financira Hrvatska zaklada za znanost.

1

ANDREJ ŽMEGAČ, Bastioni kontinentalne Hrvatske, Zagreb, 2000., 119 (Hrvatski državni arhiv, Kartografska zbirka, d XV, 6, 1531, 1532; Österreichisches Staatsarchiv, Kriegsarchiv, Beč, Inl. C VII Karlstadt 26; K VII 1 155).

2

ANDREJ ŽMEGAČ (bilj. 1), usporedba veličina na str. 40-42.

3

Országos Széchényi Könyvtár, Budimpešta, TK 1216 (»Plan C«), TK 2085 (»Plan von der Neüen Vöstung Carlstatt«), TK 2098 (»Plan A«), TK 2099 (»Plan B«).

4

Württembergische Landesbibliothek, Stuttgart, Sammlung Nicolai, sv. 104, 33r.

\section{5}

Zbog otklona osi cijeloga grada prema sjeverozapadu točnije bi bilo reći sjeveroistočni trg, no zbog pojednostavljenja u opisu ovdje se orijentacija određuje prema osnovnim stranama svijeta.

\section{6}

Plan nema legendi. Tu je potrebno skrenuti pozornost na zbirku iz koje prikaz potječe, a riječ je o zbirci Nicolai u Württembergische Landesbibliothek u Stuttgartu. Ferdinand Friedrich Nicolai (1730. - 1814.) bio je visoki časnik u württemberškoj vojsci, stvorivši zbirku nacrta koje je koristio u podučavanju mladih časnika. Zbirku je od Nicolaia 1786. otkupio württemberški vojvoda, te je ona potom postala dostupna u javnoj knjižnici, prethodnici današnje ustanove. Vjerujemo da Nicolai, skupljajući zbirku, u mnogo slučajeva nije mogao zadržati nacrte koje je pribavio, te bi stoga dao izraditi kopije. Time bi se moglo objasniti da brojni rukopisni prikazi u zbirci pokazuju - poput tlocrta Novog Karlovca - određenu redukciju detalja te pisanih informacija. Čini se da su kopisti preuzimali one informacije koje su im bile važne s obzirom na svrhu izrade kopija. No nema sumnje da su njihove kopije vjerodostojan i znalački izrađen povijesni dokument te da u svemu bitnome mogu danas nadomjestiti izvornik. Nicolai je rukopisne dokumente, kao i grafike, lijepio na listove velikih knjižnih svezaka, pa je stoga bio ograničen raspoloživim prostorom na stranici; tako se može objasniti što je i ovaj tlocrt Novog Karlovca očito obrezan, a jasno je to vidljivo na gornjem rubu gdje nedostaje dio glasije. Podatci o Nicolaiju prema HANS-CHRISTIAN PUST, Quellen zur Festungsgeschichte in der Sammlung Nicolai der Württembergischen Landesbibliothek Stuttgart, u: Die Festung der Neuzeit in historischen Quellen, Regensburg, 2018., 225, 226. 7

Ti izvještajni nacrti sadrže i jedan element koji se još uvijek razaznaje na terenu. To je zatvoreni prostor, dio bastionskog sustava u nastajanju: duži zidovi prislonjeni su na trasu buduće fase Emerikova bastiona i kontargardu ispred njega, a dva kraća zida zatvaraju bokove. Tako stvoreno dvorište očito je bilo privremeni funkcionalni element u procesu izgradnje, jer ga nema na planu koji pokazuju cjeloviti bastionski sustav.

8

Prema našem mjerenju standardna dimenzija tako određenih blokova iznosi $84 \times 60 \mathrm{~m}$.

9

Plan je objavljen u Scamozzijevu traktatu L'idea dell'architettura universale, objavljenom u Veneciji 1615., str. 166, 167.

10 Prema našem mjerenju trgovi su bili planirani u kvadratima dimenzije stranica 64,3 m. Središnji trg Karlovca, Trg sv. Trojstva, izvorno je imao dimenzije stranica kvadrata 73,7 m.

11 MILAN KRUHEK, Karlovac. Utvrde, granice, ljudi, Karlovac, 1995.; MILAN KRUHEK, Krajiške utvrde i obrana hrvatskog kraljevstva tijekom 16. stoljeća, Zagreb, 1995., 9.

12

ZLATKO UZELAC, Vrhunac razvitka osječkih baroknih fortifikacija, treća projektna faza 1727. - 1731. - doprinos Nicolasa Doxata de Démoreta, Osječki zbornik, 35 (2020.), 32-36.

13 MILAN KRUHEK, Karlovac. Utvrde, granice, ljudi (bilj. 11), 10. 


\section{Summary}

\section{Igor Čulig - Zlatko Uzelac - Andrej Žmegač The Unfinished Baroque Town-Fortress of Novi Karlovac}

The hexagonal fortress of Karlovac in central Croatia dates back to the $16^{\text {th }}$ century and was built according to the Renaissance principles of fortification architecture. In the $18^{\text {th }}$ century, the fortress was declared unsuitable for modernization, so a completely new town-fortress was intended to be built not far from it. The new fortress was supposed to be significantly larger than Karlovac and not of a regular polygonal form like the older fortress. It used the river Kupa and its sharp bend at that location for its protection, which was typical of Baroque fortresses. The new fortress of Novi Karlovac remained unfinished. Its remains are still visible today, at about $1 \mathrm{~km}$ straight line from old Karlovac, facing the spot where the Korana flows into the Kupa.

This paper focuses on several previously unpublished archival documents on Novi Karlovac, which significantly expand our knowledge of this example of Baroque fortification architecture and Baroque urban planning in Croatia. The earliest ground plan is preserved in Stuttgart, and the four depictions in Budapest date from the period when the construction had already begun. The Stuttgart ground plan shows that the fortress had weaker ramparts towards the river and understandably stronger rampart system on the other side, where greater danger could be expected. The fortress, including its inner urban construction, was evidently organized around a central axis, which passed through the central bastion and the corner at the bend of the Kupa. Important military, public, and sacral buildings are indicated within the town blocks, including a building standing in the most prominent place, in the central axis towards the river. It stands out not only with its location, but also with its completely atypical design in the context of a town-fortress, because it resembles a castle or palace. Given this special concept, it has been identified as the seat of the commander. It should be added that the document in question is probably a historical copy of an original project, as can be inferred from its reduced text: the only - but precious - note indicates the author's name: Nouveau Carlstadt par Doxat.

Designs from Budapest reveal that the construction began according to Doxat's plans, yet slightly altered: the urban organization of the blocks is different, the two side squares are formed differently, and the canalized Orlica stream running through the fortress before flowing into the Kupa is indicated. Above all, the lavish seat of the commander is missing; instead, a church is indicated in the most prominent place in the central square. This church, ellipsoid in its main volume, is reminiscent of the Peterskirche in Vienna, just completed at the time (1732-1733), and given the friendship between Eugene of Savoy and the architect, Johann Lucas von Hildebrandt, one may presume that the church designed for the new town-fortress was the latter's work as well.

Novi Karlovac was part of a long system of fortifications built under guidance Eugene of Savoy, stretching from Transylvania in the east to Karlovac in the west. There were fifteen of these towns-fortress, and in most of them modernization meant not only building the most state-of-the-art fortification structures, but also a radical baroque transformation of the previously oriental urban construction after the conquest of these Ottoman towns. From 1722, Eugene's chief fortification engineer in the area was Nicolas Doxat de Démoret (1682-1738), who carried out the modernization or construction of most of these towns-fortresses, including Novi Karlovac.

The construction began in 1733, but was halted the following year due to altered historical circumstances, which persisted after the death of Prince Eugene of Savoy (1736) and the end of the reign of Emperor Charles VI (1740).

Keywords: Baroque urban planning, fortification architecture, newly planned towns, Karlovac, Prince Eugene of Savoy, Nicolas Doxat de Démoret, Johann Lucas von Hildebrandt 